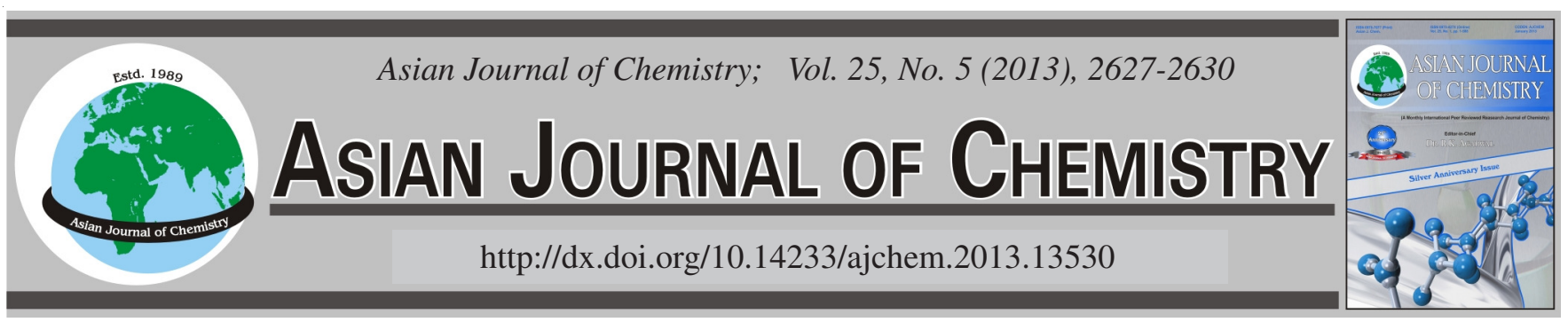

\title{
Study of Excess Sludge Reduction in Conventional Activated Sludge Process by Heating Returned Sludge
}

\author{
Parviz Mahmoudi ${ }^{1}$, Afshin Takdastan ${ }^{2, *}$, Nadali Alavi ${ }^{1}$, Ali A.J. Mosavi ${ }^{1}$ and Neda Kaydi ${ }^{1}$
}

\begin{abstract}
${ }^{1}$ Department of Environmental Health, Ahvaz Jondi Shapour University of Medical Sciences, Ahvaz, Iran
${ }^{2}$ Department of Environmental Health and Environmental Technology Research Centre, Ahvaz Jondi Shapour University of Medical Sciences, Ahvaz, Iran
\end{abstract}

*Corresponding author: E-mail: afshin_ir@yahoo.com

(Received: 30 January 2012;

Accepted: 15 November 2012)

AJC-12416

\begin{abstract}
The use of conventional activated sludge as a biological wastewater treatment process has been employed to treat a wide variety of wastewater. The ultimate disposal of excess sludge generated from activated sludge processes has been one of the most challenging problems for waste water treatment utilities in order to solve the problem of excess sludge production. This paper investigated the effect of temperature on excess sludge reduction in activated sludge process, therefore, returned sludge temperature was increased from 30 to $70{ }^{\circ} \mathrm{C}$, stepwise every $10{ }^{\circ} \mathrm{C}$ at the time concentrating on each step for $1 \mathrm{~h}$. After reaching steady state in the system, we made use of sampling and testing parameters such as COD, MLSS, MLVSS, SVI, $\mathrm{BOD}_{5}$ and yield coefficient. Results showed that increasing the temperature from 30 to $40^{\circ} \mathrm{C}$ increased the yield coefficient from 0.68 to 0.73 . Further increase of the temperature up to $60{ }^{\circ} \mathrm{C}$ reduced the yield coefficient to 0.33 and increased residual COD in the effluent from 89 to $195 \mathrm{mg} / \mathrm{L}$, which is less than agricultural reuse standard. Also in this temperature, sludge reduction rate was about $46.8 \%$ and SVI rate was about $44 \mathrm{mg} / \mathrm{L}$. At $70{ }^{\circ} \mathrm{C}$ increase in effluent COD and turbidity was noticed. It also did not meet the wastewater disposal standard and the wastewater gave out bad odor and had bad yield coefficient.
\end{abstract}

Key Words: Activated sludge process, Sludge reduction, Temperature, Yield coefficient, Excess sludge.

\section{INTRODUCTION}

Biological wastewater treatment includes the transformation of dissolved and suspended organic contaminants to biomass and evolved gases of $\left(\mathrm{CO}_{2}, \mathrm{CH}_{4}, \mathrm{~N}_{2} \text { and } \mathrm{SO}_{2}\right)^{1}$. Excess sludge treatment and disposal represents a rising challenge for small and mid-scale municipal wastewater treatment plants (WWTPs) due to economic, environmental and regulation factors ${ }^{2}$.

The use of conventional activated sludge as a biological wastewater treatment process has been employed to treat a wide variety of wastewater ${ }^{3}$. The wide application of activated sludge process in domestic and industrial treatment plants has amplified sludge management problems ${ }^{4}$. However, its primary by-product, excess sludge, has become a large problem; the major drawback in activated sludge processes is high excess sludge production ${ }^{3,5}$. About $60 \%$ of the total operation cost in a sewage treatment plant is accounted for sludge storage, transport, digestion and disposal ${ }^{3}$.

Therefore; it is important to develop methods for reducing excess sludge produced during wastewater treatment in a manner, which is practical and also environmentally and economically safe $^{2}$.
Currently, different bio-engineering technologies such as lysis-cryptic growth, uncoupling metabolism, maintenance metabolism and predation on bacteria, are being developed for sludge reduction ${ }^{2}$. Prorot et al. ${ }^{6}$ resulted that, a decrease in the number of active cells, subsequent to the thermal treatment had accorded.

Heat-treatment has been used to reduce excess sludge as a simple process ${ }^{7}$. The reduction of excess sludge by heattreatment is induced by sludge lysis and further cryptic growth (lysis-cryptic growth) $^{8}$. In the lysis-cryptic growth, sludge reduction is achieved because some portions of lysates are consumed by the catabolism and finally emitted as $\mathrm{CO}_{2}$. Consequently, the microbial community succession in the sludge should occur during heat-treatment. With the development of molecular microbiological techniques, denaturing gradient gel electrophoresis (DGGE) analysis of PCR-amplified 16S rDNA has been used as a useful tool to analyze the diversity of a microbial community ${ }^{9}$.

Heat-treatment is considered to be simple to operate compared to other treatments such as ozonation, chlorination, having the capability of separate or combined application with other methods, such as alkaline or acid treatment ${ }^{8}$. 
TABLE-1

EFFECT OF TEMPERATURE ON YIELD COEFFICIENT, COD REMOVAL, SVI, BOD 5 , TSS AND SLUDGE REDUCTION

\begin{tabular}{|c|c|c|c|c|c|c|}
\hline Sludge temperature $\left({ }^{\circ} \mathrm{C}\right)$ & $\begin{array}{c}\text { Yield coefficient } \\
\text { (mg biomass/mg COD) }\end{array}$ & COD removal & $\mathrm{SVI}(\mathrm{mL} / \mathrm{g})$ & $\mathrm{BOD}_{5}$ & TSS (mg/L) & $\begin{array}{c}\text { Sludge } \\
\text { reduction }(\%)\end{array}$ \\
\hline 23 (waste water temperature) & 0.62 & 89 & 92 & 22 & 46 & - \\
\hline 30 & 0.68 & 91 & 115 & 18 & 40 & +9.7 \\
\hline 40 & 0.73 & 93 & 137 & 14 & 31 & +17.7 \\
\hline 50 & 0.39 & 81 & 82 & 81 & 66 & -37.1 \\
\hline 60 & 0.33 & 61 & 44 & 109 & 91 & -46.8 \\
\hline 70 & - & 9 & - & 360 & 235 & - \\
\hline
\end{tabular}

Sludge reduction is achieved by cryptic growth of microorganisms, i.e. microbial growth on its lysates. Therefore, few cell breakage techniques have been developed, of which we could mention; sludge treatment by thermal, alkaline, acid and the combination of thermal treatment with either of above mentioned treatments ${ }^{10,11}$. It was found that in thermalchemical hydrolysis, sodium hydroxide was the most efficient for inducing cell lysis ${ }^{10}$. Further research showed that the biodegradation of the soluble fraction of the lysates by fresh sludge reached $75 \%$ after 48 and $90 \%$ after 350 h of incubation respectively and a reduction of $37 \%$ of the excess sludge was obtained without altering the purification yield of the process $^{11}$.

Canals et al., ${ }^{12}$ reported that thermal treatment at $90{ }^{\circ} \mathrm{C}$ for $3 \mathrm{~h}$ led to a 2.5 -fold decrease of the observed growth yield and a 3 -fold increase of sludge maintenance coefficient ${ }^{12}$.

In this work, part of sludge was heated gradually from 30 up to $70^{\circ} \mathrm{C}$ for $5 \mathrm{~h}$, every $10^{\circ}$ at the time for $1 \mathrm{~h}$ in order to reduce biological excess sludge.

\section{EXPERIMENTAL}

In this research, one activated sludge reactor used with rectangular cubic shaped Plexiglas tank, including aeration tank with $8 \mathrm{~L}$ efficient volume, $30 \mathrm{~cm}$ length, $15 \mathrm{~cm}$ wide and $18 \mathrm{~cm}$ height and settling tank with $3 \mathrm{~L}$ efficient volume, $20 \mathrm{~cm}$ length, $15 \mathrm{~cm}$ wide and $17.5 \mathrm{~cm}$ height. Fig. 1 demonstrates schematic diagram of activated sludge reactor.

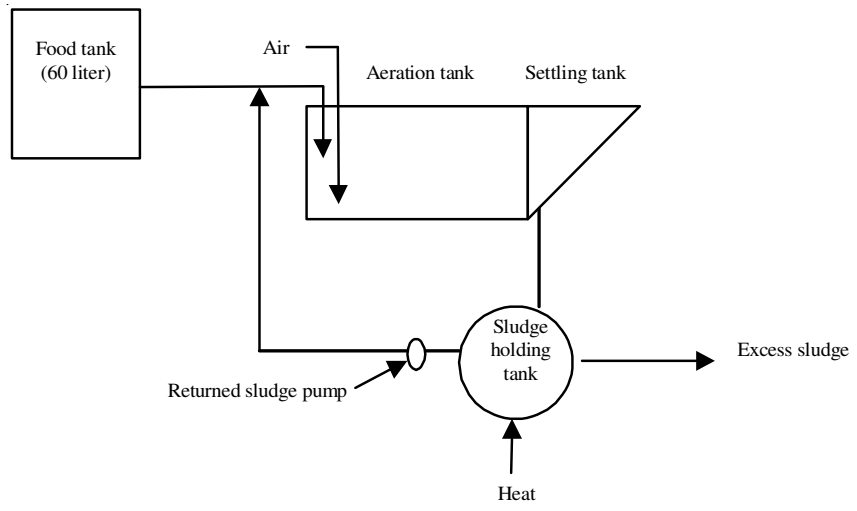

Fig. 1. Schematic diagram of activated sludge process

Synthetic wastewater characteristics: The synthetic wastewater of this pilot scale treatment plant was made by the mixture of $10 \mathrm{mg}$ industrial dry milk with $60 \mathrm{~L}$ tap water. The characteristics of wastewater in this experiment were as follows: COD: $500 \mathrm{mg} / \mathrm{L}$; $\mathrm{BOD}_{5}$ : $350 \mathrm{mg} / \mathrm{L}$; Nitrogen (as nitrate): $3.3 \mathrm{mg} / \mathrm{L}$ as $\mathrm{N}$; Nitrogen (as organic nitrogen): 21
mg/L as N; Nitrogen (as TKN): $21.4 \mathrm{mg} / \mathrm{L}$ as N; Phosphor: 14 $\mathrm{mg} / \mathrm{L}$ as $\mathrm{P}$.

Pilot start up: As the first step $2 \mathrm{~L}$, from the aforementioned returned activated sludge of the domestic wastewater treatment plant of Ahvaz-Chonaibieh, was mixed with aeration tank $(8 \mathrm{~L})$ in order to operate the conventional activated sludge (CAS).

The system was operated for about a month at a flow rate of $30 \mathrm{~L} / \mathrm{d}$. During this stage the amount of dissolved oxygen was kept as much as 1.5 to $2 \mathrm{mg} / \mathrm{L}$ and the parameters of effluent COD and TSS were tested until the steady state was reached.

After reaching the steady state, within 6 months the parameters COD, $\mathrm{BOD}_{5}$, MLSS, MLVSS, MLNVSS, SVI and DO were measured yielding kinetics were also calculated. The tests were performed according to standard methods for the examination of water and wastewater ${ }^{13}$.

To calculate the yielding kinetics the following formula was used:

$$
\mathrm{dx} / \mathrm{dt}=\mathrm{Y} \mathrm{ds} / \mathrm{dt}
$$

where, $\mathrm{dx} / \mathrm{dt}$ : The increase rate in biomass concentration or MLSS (mg/L); ds/dt : The removal rate of substrate or COD $(\mathrm{mg} / \mathrm{L})$.

On the other hand to calculate Y (yield coefficient) this formula can also be used:

$$
\mathrm{Y}=\frac{\mathrm{X}_{\mathrm{t}}-\mathrm{X}_{0}}{\mathrm{~S}_{0}-\mathrm{S}_{\mathrm{e}}}
$$

where, $\mathrm{X}_{0}, \mathrm{X}_{\mathrm{t}}$ : Primary and ultimate biomass concentration $(\mathrm{mg} / \mathrm{L})$ respectively; $\mathrm{S}_{0}, \mathrm{~S}_{\mathrm{e}}$ : Primary and ultimate substrate concentration $(\mathrm{mg} / \mathrm{L})$ respectively ${ }^{14}$.

Variable situation: After the change in temperature of returned sludge, 6 days were considered for the system to be adapted to the new situation. Within these 6 days effluent COD and TSS, were analyzed until concentration changes of COD and TSS fell below $10 \%$, which is statistically acceptable. In order to confirm the validity of the experiments, they were repeated 3 times.

\section{RESULTS AND DISCUSSION}

After established steady state in room temperature and reached retention time to 10 days, the amount of yield coefficient was $0.62 ; \mathrm{mg}$ biomass $/ \mathrm{mg}$ COD, while at temperatures 50 and $60{ }^{\circ} \mathrm{C}$ reached to 0.39 and 0.33 respectively (Table- 1 ).

Effect of temperature on yield coefficient: Establishing steady state, room temperature, retention time reached 10 days and yield coefficient was $0.62 \mathrm{mg}$ biomass $/ \mathrm{mg}$ COD. Available results indicate that increasing the temperature of returned sludge from 30 to $40{ }^{\circ} \mathrm{C}$, increased sludge yield coefficient 
0.62 to 0.73 . This could be attributed to the increase in bacterial activities which increases the rate of degradation of organic matter consequently the biomass production. Further increase of the temperature of the temperature of returned sludge to $60{ }^{\circ} \mathrm{C}$, reduced the yield coefficient to 0.33 because sludge bacterial cell lysis and many microorganisms die in the reactor (except for limited number of slim microorganisms which can tolerate) (Table-1 and Fig. 2).

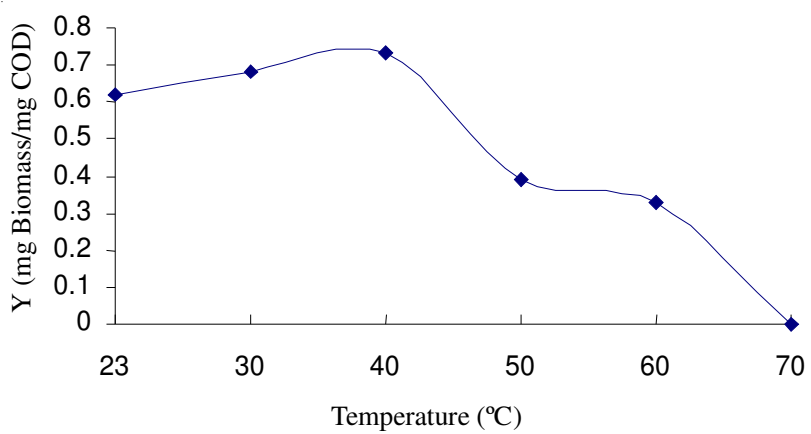

Fig. 2. Effect of temperature on Yield coefficient

Effect of temperature on removal of COD: According to Fig. 3 as the sludge temperature had increased from wastewater temperature to $40{ }^{\circ} \mathrm{C}$, the COD removal percentage did not change, however when the temperature reached $60{ }^{\circ} \mathrm{C}$ massive cell lysis occurred, accordingly. The COD removal percentage gradually decreased and reached $60 \%$. But increasing the temperature over $60^{\circ} \mathrm{C}$ would cause cell inactivation and kill a lot of heterotrophic microorganisms. Therefore the soluble COD rate increased appreciably in the effluent and resulted in the massive decrease of COD removal percentage, till falling below $10 \%$.

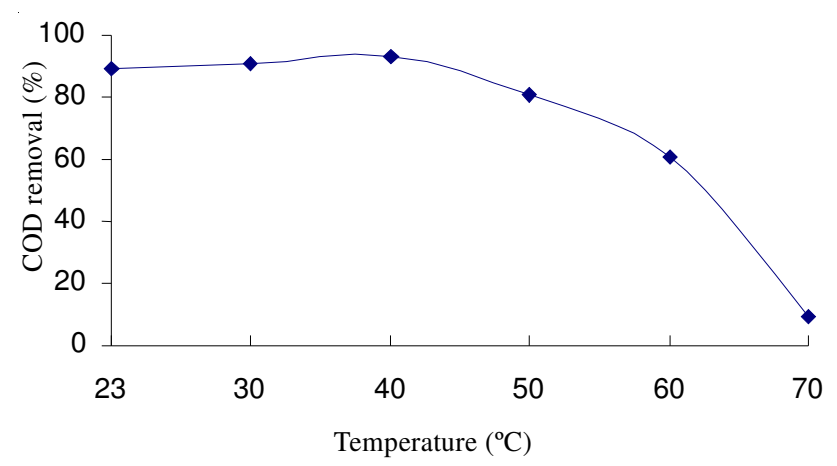

Fig. 3. Effect of temperature on COD removal percentage

Effect of temperature on SVI: Fig. 4 shows experimental results of the SVI with changes of temperature, according to results, SVI value increase from 92 to $137 \mathrm{~mL} / \mathrm{g}$ with temperature rising from room temperature to $40{ }^{\circ} \mathrm{C}$ and further increased to $60{ }^{\circ} \mathrm{C}$ reduced the SVI to around $44(\mathrm{~mL} / \mathrm{g})$. On the other hand increasing the temperature would cause MLVSS/MLSS ratio decrease and thus a slight increase in the specific weight of sludge.

Comparison of effluent COD with wastewater disposal and reuse standards: Fig. 5 shows the comparison of effluent wastewater COD with Iran wastewater disposal standards and agriculture reuse standard in different temperatures. Fig. 5 showed that at $40{ }^{\circ} \mathrm{C}$ the amount of effluent COD is below wastewater disposal standards, but at temperatures higher than $40^{\circ} \mathrm{C}$, COD values did not match those of wastewater disposal standards. However between 40 to $60^{\circ} \mathrm{C}$ it meets the agriculture reuse standard. At temperatures higher than $60^{\circ} \mathrm{C}$ effluent COD exceeds the standard level of agricultural reuse.

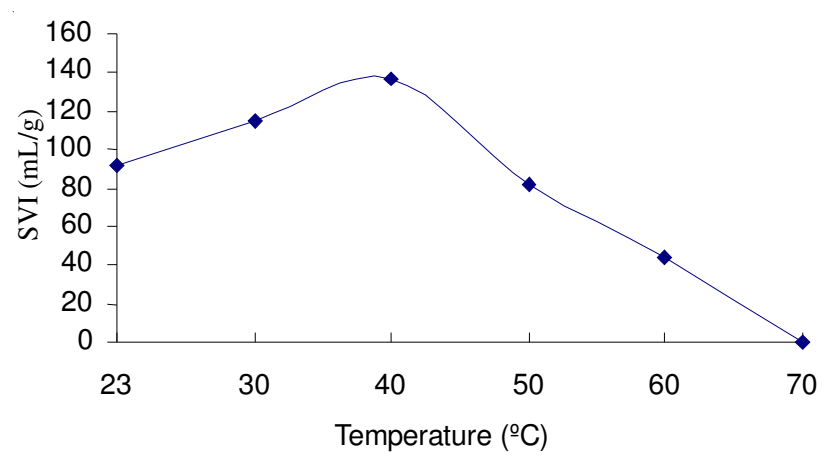

Fig. 4. Effect of temperature on SVI

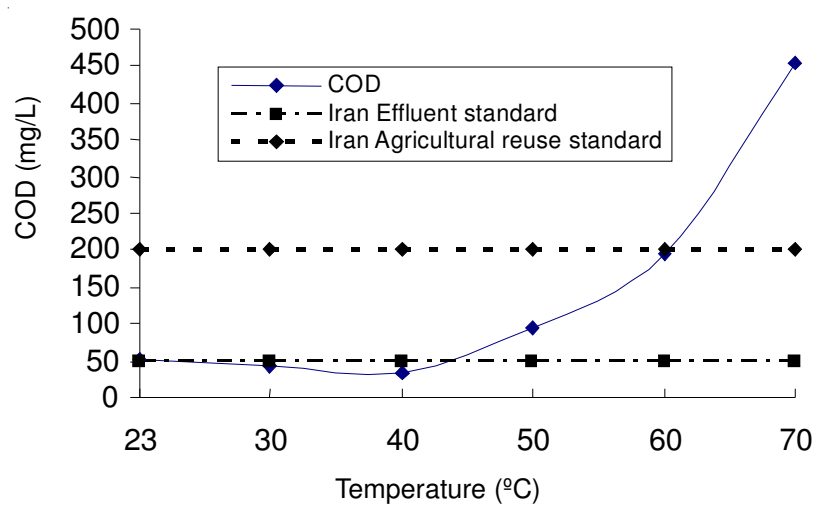

Fig. 5. Comparison of effluent wastewater COD removal with Iran effluent standard and Iran agricultural reuse standard in different temperatures

Comparison with other studies: Table-2 compares the results of this study with other thermal techniques for sludge reduction. Taking the time and amount of heating in this study into the consideration it is clear that the results of this study show a slight improvement compared to the similar studies performed previous to this one.

TABLE-2

THERMAL TECHNIQUES FOR REDUCTION OF SLUDGE REDUCTION

\begin{tabular}{lcc}
\hline Operation condition & $\begin{array}{c}\text { Sludge } \\
\text { reduction }(\%)\end{array}$ & Ref. \\
\hline $\begin{array}{l}\text { 1. Urban wastewater }\left(65^{\circ} \mathrm{C}, 48 \mathrm{~h}\right) \\
\text { 2. Thermal treatment lab scale }\left(90{ }^{\circ} \mathrm{C}, 3 \mathrm{~h}\right)\end{array}$ & 60 & 15 \\
3. Membran bioreactor, synthetic waste & 37 & 12 \\
water, lab scale $\left(60^{\circ} \mathrm{C}, 20\right.$ min, $\left.\mathrm{pH}=10\right)$ & & \\
4. Pilot plant scale, synthetic waste water, & & \\
$\left(50\right.$ to $\left.70{ }^{\circ} \mathrm{C}, 1 \mathrm{~h}\right) \mathrm{SBR}$ : & 39 & \\
a. $50^{\circ} \mathrm{C}$ & 47 & \\
b. $60^{\circ} \mathrm{C}$ & 100 & \\
c. $70^{\circ} \mathrm{C}$ & & This \\
$5 . \mathrm{Pilot}^{\circ}$ plant scale, synthetic waste water, & & \\
$\left(50\right.$ to $\left.70^{\circ} \mathrm{C} 1 \mathrm{~h}\right)$ activated sludge reactor: & 37.1 & study \\
a. $50^{\circ} \mathrm{C}$ & 46.8 & \\
b. $60^{\circ} \mathrm{C}$ & 100 & \\
c. $70^{\circ} \mathrm{C}$ & &
\end{tabular}




\section{Conclusion}

The performance of sludge reduction by heating returned activated sludge was investigated and conclusions were made as follows:

(a) With heating sludge from 23 to $60{ }^{\circ} \mathrm{C}$, the COD removal percentage began to decrease and reached $61 \%$ due to solubilization of extra-cellular polymeric substance (EPS) and microbial lysis.

(b) The amount of SVI after these changes reduced from $92 \mathrm{~mL} / \mathrm{g}$ to $44 \mathrm{~mL} / \mathrm{g}$.

(c) The value of Yield coefficient was $0.62 \mathrm{mg}$ biomass/ $\mathrm{mg}$ COD at room temperature but with increase of temperature to $40{ }^{\circ} \mathrm{C}$ for an hour in retuned sludge, yield coefficient increased to 0.73 .

(d) Decrease of the yield coefficient occurred after increasing temperature up to $60^{\circ} \mathrm{C}$ where the yield coefficient reached 0.33 due to sludge bacterial cell lysis and death of many organisms in the reactor.

(e) Also excess sludge reduced to $46.8 \%$.

(f) At high temperature $\left(70^{\circ} \mathrm{C}\right)$, biological excess sludge did not produce and the effluent COD increased and did not comply with wastewater reuse standards.

\section{ACKNOWLEDGEMENTS}

The authors are grateful for financial support of this project by research council of Ahvaz Jundishapur University of Medical Sciences.

\section{REFERENCES}

1. E. Low, W. Chase and A. Howard, Water Res., 33, 1119 (1999).

2. Y. Wei, Y. Wang, X. Guo and J. Liu, J. Hazard. Mater., 163, 87 (2009).

3. S. Yan, T. Zheng, H. Li, A. Zhang, X.H. Xing, L.B. Chu, G. Ding, X.L. Sun and B. Jurcik, Bioresour. Technol., 100, 5002 (2009).

4. Y. Tian, Y. Lu, L. Chen and H. Lin, Bioresour. Technol., 101, 6069 (2010).

5. C. Rai and P. Rao, Clean Technol. Environ. Policy, 11, 437 (2009).

6. A. Prorot, C. Eskicioglu, R. Droste, C. Dagot and P. Leprat, J. Ind. Microbiol. Biotechnol., 35, 1261 (2008).

7. S. Yan, K. Miyanaga, X.H. Xing and Y. Tanji, Biochem. Engg. J., 39, 598 (2008)

8. Y. Wei, H. Van, T. Renze, A.R. Borger, D.H. Eikelboom and Y. Fan, Water Res., 37, 4453 (2003).

9. G. Muyzer, E. Wall and A. Uitterlinden, Environ. Microbiol., 59, 695 (1993).

10. M. Rocher, G. Goma, B.A. Pilas, L. Louvel and J.L. Rols, Appl. Microbiol. Biotechnol., 51, 883 (1999).

11. M. Rocher, G. Roux, G. Goma, B.A. Pilas, L. Louvel and J.L. Rols, Excess Sludge Reduction in Activated Sludge Processes by Integrating Biomass Alkaline Heat Treatment. London, ROYAUME-UNI, IWA Publishing (2001).

12. A. Canales, A. Pareilleux, J. Rols, G. Goma and A. Huyard, Water Sci. Technol., 30, 97 (1994).

13. Apha, AWWA, WPCF, Standard Method for the Examination of Water and Wastewater NW, Washington D.C; edn. 22 (1992).

14. M. Pazoki, A. Takdastan and N. Jafarzadeh, Asian J. Chem., 22, 1751 (2010).

15. S.L.A. Deleris, V. Geaugey and T. Lebrunn, Innovative Strategies for the Reduction of Sludge Production in Activated Sludge Plant: BIOLYSIS O and BIOLYSIS E Proceeding of the International Water Association (IWA) Specialist Conference: Biosolids Trondheim, Norway (2003). 